\title{
Comparative analysis between steel and armed concrete structures
}

The execution of a building goes through several processes and stages in order to obtain the final result and with the construction of increasingly tall and slender buildings, the analysis of the structure becomes something of extreme importance for the safety, durability and good performance of a building. With civil construction in constant technological advances, several methods are presented to improve performance and project planning. Therefore, this article aims to present comparative methods of structural modeling and design in steel and reinforced concrete construction systems. Thus, the comparison between the two structural systems occurred with the aid of the Robot Structural Analysis 2020 and Revit 2020 software, two initial models were defined, namely, model I in reinforced concrete structure and model II in steel structure. For this assessment, the properties of the materials used, costs in relation to the materials, current standards and the agents that can influence the performance of the building, parameters such as global stability, displacement of elements and moments in the studied structural system were also considered. After processing both models, the results were analyzed and compared, demonstrating which of the methods is most viable and safe for execution.

Keywords: Structural System; Steel; Reinforced Concrete; Structural Comparative.

\section{Análise comparativa entre estruturas de aço e de concreto armado}

A execução de um edifício passa por vários processos e etapas para que se obtenha o resultado final e com a construção de prédios cada vez mais altos e esbeltos, a análise da estrutura torna-se algo de extrema importância para a segurança, durabilidade e bom desempenho de uma edificação. Com a construção civil em constantes avanços tecnológicos, vários métodos são apresentados para melhorias no desempenho e projeção de obras. Sendo assim, este artigo tem por objetivo apresentar métodos comparativos de modelagem e dimensionamento estrutural em sistemas construtivos de aço e de concreto armado. Deste modo, o comparativo entre os dois sistemas estruturais ocorreu com o auxílio dos softwares Robot Structural Analysis 2020 e Revit 2020 , foram definidos dois modelos iniciais, sendo, o modelo I em estrutura de concreto armado e o modelo II em estrutura de aço. Para essa avaliação também foram consideradas as propriedades dos materiais empregados, custos em relação aos materiais, normas vigentes e os agentes que podem influenciar no desempenho da edificação, parâmetros como estabilidade global, deslocamentos de elementos e momentos no sistema estrutural estudado. Após o processamento dos dois modelos, os resultados foram analisados e comparados, demonstrando qual dos métodos é mais viável e seguro para execução.

Palavras-chave: Sistema Estrutural; Aço; Concreto Armado; Comparativo Estrutural.

Topic: Engenharia de Estruturas

Reviewed anonymously in the process of blind peer.
Received: $11 / 04 / 2020$

Approved: 29/07/2020
Andressa Volpato Zucolli (iD

Instituto Tocantinense Presidente Antônio Carlos, Brasil

http://lattes.cnpq.br/7545501004481941

http://orcid.org/0000-0001-9240-6881

andressazucolli.avz@gmail.com

Douglas Freitas Augusto dos Santos (id

Instituto Tocantinense Presidente Antônio Carlos, Brasil

http://lattes.cnpq.br/6181125172616043

http://orcid.org/0000-0001-9306-5660

eng.prof.santos@gmail.com
Referencing this:

ZUCOLLI, A. V.; SANTOS, D. F. A.. Comparative analysis between steel and armed concrete structures. Engineering Sciences, v.8, n.2, p.4557, 2020. DOI: http://doi.org/10.6008/CBPC2318-3055.2020.002.0005 


\section{INTRODUCTION}

Innovations constantly appear in civil engineering, whether in materials or construction methods, making it possible for engineering works to become increasingly larger, more resistant, sophisticated and of quick execution. In addition, technologies such as software assist more and more efficiently in the design of projects, making them more secure and economical, since through these computer programs more accurate calculations can be obtained.

In Brazil, the construction method most used for many years is reinforced concrete, but currently the steel structures are gaining space. It is a method that can be executed in a shorter time, it does not generate so many rejects, it allows larger free spans and a lighter structure, consequently reducing the expenses with foundations when compared with conventional structures. In order to meet the growing demand in the industrialized civil construction market, steel started to be used in the form of imported prefabricated structures, thus several applications were developed, from metal bridges to the most modern commercial and residential buildings (CORTEZ, 2017).

On the other hand, metallic structures require specialized labor, in addition, they do not have easy accessibility, which can cause inconvenience and make the work more expensive in some places due to transport. Reinforced concrete structures require less qualified labor for their execution, this method also allows molding of the structure with the aid of formwork and presents high resistance when compared to other construction forms, as it is a solidary connection of concrete with a material resistant to traction, which in general is steel (BOTELHO et al., 2010).

Thus, it is difficult to define which of the construction methods becomes more viable and appropriate. Thus, the present study aimed to make a comparison between reinforced concrete and steel structures, for a particular building used for the study. For the evaluation between the methods, current rules and agents that influence the performance of the building, the Structural Analysis and Revit software were used for a more accurate comparison, which are capable of modeling the building under study in two structural methods analyzed, namely, model I reinforced concrete structure and model II steel structure.

\section{METHODOLOGY}

\section{Building Description}

The comparative analysis carried out in this work was based on a hypothetical building used for the present study, located in the city of Porto Nacional, in the state of Tocantins, on a lot in front of ITPAC PORTO, in the Jardim dos Ypês II sector. It has four types of floors, with 3.10 meters of height each floor and a reservoir with a height of 3 meters, totaling a maximum height for the building of 15.40 meters, from the ground zero level. Figure 1 shows the building's floor plan, each floor comprising a social hall, stairs, four rooms and four bathrooms (one in each room). 


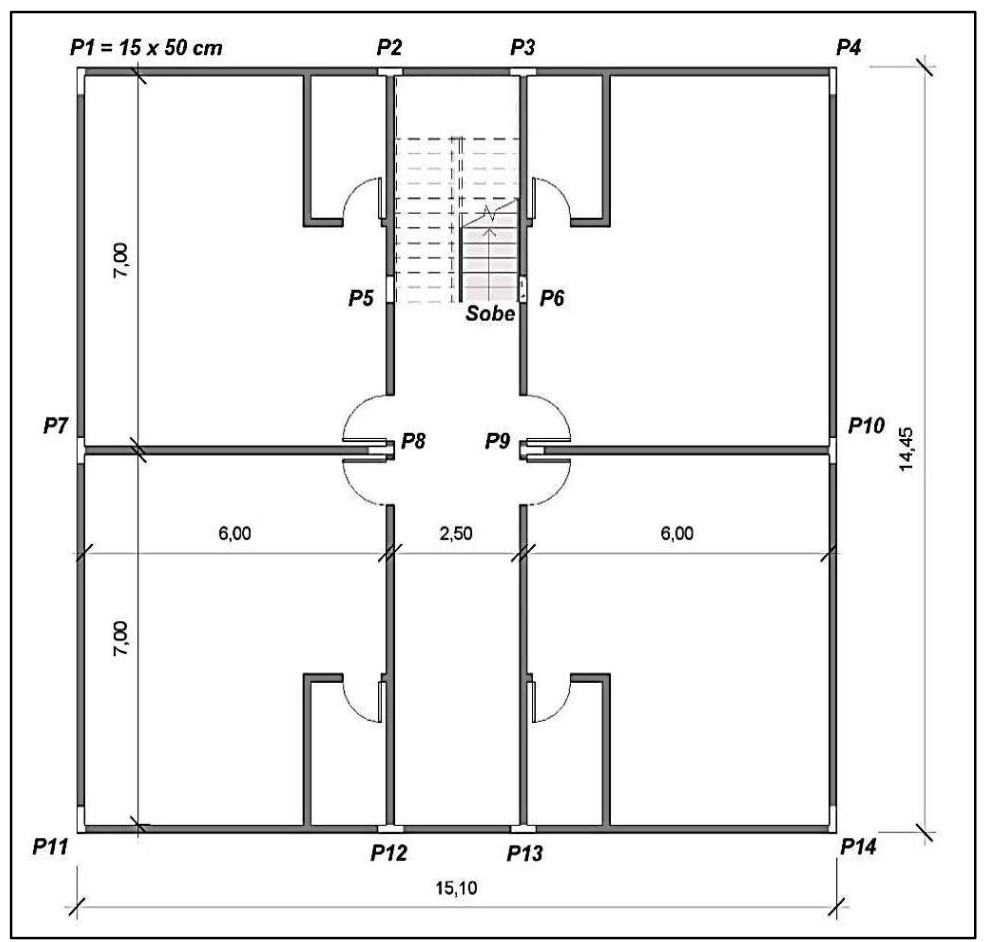

Figure 1: Low type plant.

\section{Lifting of loading models I and II}

The values admitted for the building are shown in table 1, and were based on ABNT NBR 6120 (1980).

Table 1: Lifting the loads.

\begin{tabular}{|l|l|}
\hline LOADING & SPECIFIC WEIGHT OF MATERIALS \\
\hline Own weight of the Reinforced Concrete Structure & $25,0\left(\mathrm{KN} / \mathrm{m}^{3}\right)$ \\
\hline Steel Structure own weight & $7,85\left(\mathrm{Kg} / \mathrm{m}^{3}\right)$ \\
\hline Walls & $13,0\left(\mathrm{KN} / \mathrm{m}^{3}\right)$ \\
\hline LOADING & MINIMUM VALUES OF VERTICAL LOADS \\
\hline Coating & $1,0\left(\mathrm{KN} / \mathrm{m}^{2}\right)$ \\
\hline Overhead Coverage & $0,5\left(\mathrm{KN} / \mathrm{m}^{2}\right)$ \\
\hline Overload Type & $2,0\left(\mathrm{KN} / \mathrm{m}^{2}\right)$ \\
\hline
\end{tabular}

Source: Adapted from ABNT NBR 6120 (1980).

\section{Calculation of wind actions according to NBR 6123 (2013)}

Determinations of forces due to the wind are governed and calculated according to ABNT NBR 6123 (2013), a rule that regulates the conditions required in the consideration of forces to the static and dynamic action of the wind, for the purpose of calculating the building. The wind actions are determined from the specifications of the location where the building will be built. The basic wind speed $\left(V_{0}\right)$ is indicated by the NBR 6123 isopletas, for the region where the building is located, $V_{o}=30 \mathrm{~m} / \mathrm{s}$; Topographic factor $\left(\mathrm{S}_{1}\right)$ is defined according to the characteristics of the land where the building is located: Flat or slightly hilly terrain, thus, $\mathrm{S}_{1}=1.0$.

Roughness factor $\left(\mathrm{S}_{2}\right)$ is divided into categories, depending on the obstacles around the terrain. According to the location, it was classified as: Category IV - Land covered by numerous and little spaced obstacles, in forested, industrial or urbanized areas, average height of obstacles of $10 \mathrm{~m}$. To determine the class, the largest dimension of the building under study is taken into account: Class A - Any building in which 
the largest horizontal or vertical dimension does not exceed $20 \mathrm{~m}$. Thus, it was obtained $(b=0.86 ; p=0.12 ; F$ $r=0.98)$; For the statistical factor $\left(S_{3}\right)$, considering the degree of security and the useful life of the building, it was classified as: group 2 - commercial building, where $S_{3}=1.0$.

From equations 1, 2 and 3 , it was possible to calculate the values of $V_{k}$ (characteristic wind speed), $q$ (dynamic wind pressure) and $\mathrm{F}_{\mathrm{a}}$ (Drag force), respectively, shown in table 2. drag describes the force that will be applied to the nodes of each floor of the building, to determine the value for the drag coefficient, the abacus and the equations available in ABNT NBR 6123 (2013) are used.

$$
\begin{array}{ll}
V_{k}=V_{o} \cdot S_{1} \cdot S_{2} \cdot S_{3} & \text { Equation 1 } \\
q=0,613 \cdot V_{k}{ }^{2} & \text { Equation 2 } \\
F_{a}=C_{a} \cdot q_{v} \cdot A_{e} & \text { Equation 3 }
\end{array}
$$

Table 2: Actions of the Wind.

\begin{tabular}{|l|l|l|l|}
\hline$Z(m)$ & $V_{k}(\mathbf{m} / \mathbf{s})$ & $q\left(N / \mathbf{m}^{2}\right)$ & $F_{a}(K N)$ \\
\hline $\mathbf{3}$ & 21,96 & 295,61 & 12,33 \\
\hline $\mathbf{6 , 2}$ & 23,88 & 349,56 & 14,54 \\
\hline $\mathbf{9 , 3}$ & 25,05 & 384,66 & 16,04 \\
\hline $\mathbf{1 2 , 4}$ & 25,95 & 412,79 & 8,6 \\
\hline $\mathbf{1 5 , 4}$ & 26,64 & 435,04 & 1,52 \\
\hline
\end{tabular}

\section{Combinations}

SIt is known that all structures are subject to actions, so it is necessary to consider them. The combinations shown below were performed based on the ultimate limit state.

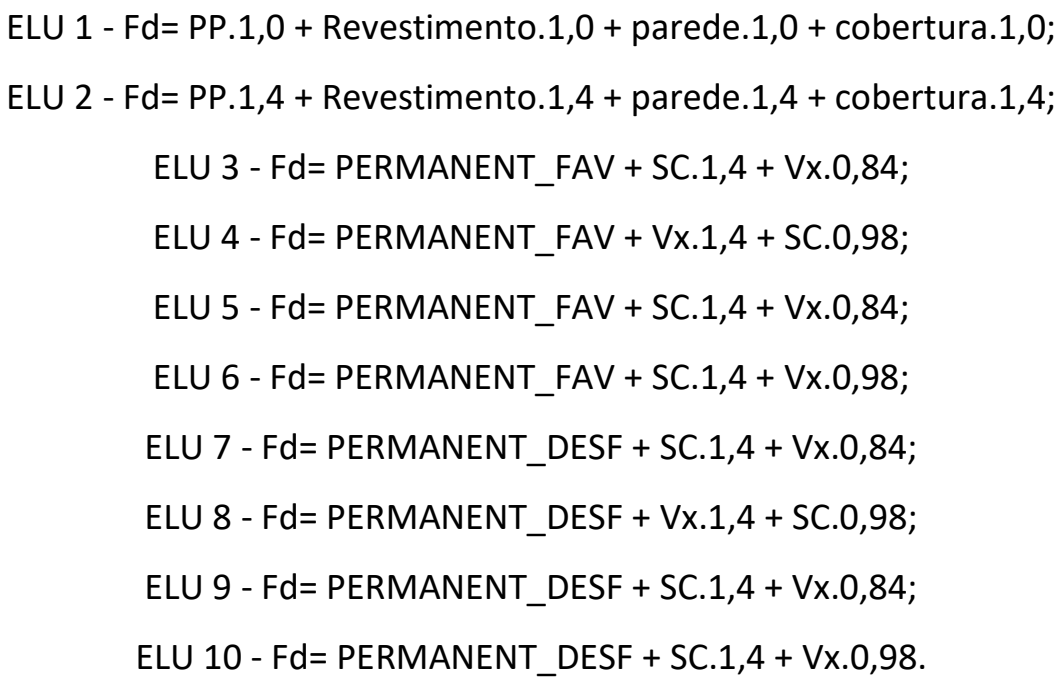

Where: PP = Own Weight; $E L U=$ ultimate limit state; Perm = Permanent Loads; DESF. = Unfavorable loads;

FAV = Favorable loads; SC = Overload;

$\mathrm{Vx}$ and $\mathrm{Vy}=$ Wind forces according to the plant coordinates.

\section{Structural modeling}

Robot Structural Analysis and Revit software were used for the modeling and dimensioning of 
buildings, from which it was possible to calculate the model I structure in reinforced concrete and also the model II structure in steel, with the possibility of calculating the two structural methods by the same software, the results for the feasibility comparison between the two models become more accurate. The software used is versatile enough to cover the analysis of finite elements from the simplest to the most complex frame.

The initial modeling of the structural elements (slabs, beams, columns and foundation) was carried out with the aid of the Revit 2020 software, considering factors such as permanent loads (own weight, coating and sealing walls) and variable loads (wind and overload actions), which had already been calculated following the normative guidelines of ABNT NBR 6120 (2014) and ABNT NBR 6123 (2013) for application in the software.

\section{Model I-Reinforced concrete}

For the reinforced concrete structure the concrete used was class C30, specified for the project with $f_{c k} 30 \mathrm{MPa}$, it was used in beams, columns and slabs of the building. The modulus of elasticity was calculated according to NBR 6118 (2014), by equation 4, obtaining a value of 23,250.0 MPa.

For fck from $20 \mathrm{MPa}$ to $50 \mathrm{MPa}$ :

$$
E_{c i}=\alpha_{E} \cdot 5600 f_{c k}
$$

The admitted steel was CA-50A, according to the recommendations of NBR 6118 (2014), adopting a Poisson's ratio of 0.2. In Brazil, the steel bars used in reinforced concrete structures are established by the NBR 7480 (2007) standard. To use the Brazilian standard bars it was necessary to make reinforcement configurations in Robot Structural Analysis, composing their dimensions and nominal mass, as shown in table 3.

Table 3: Characteristics of the bars.

\begin{tabular}{|l|l|l|l|l|}
\hline $\begin{array}{l}\text { NOMINAL DIAMETER } \\
(\mathrm{mm})\end{array}$ & \multicolumn{2}{|l|}{ MASS AND TOLERANCE BY UNIT OF LENGTH } & \multicolumn{2}{l|}{ NOMINAL VALUES } \\
\hline Bars & $\begin{array}{l}\text { Nominal mass (Kg / } \\
\mathrm{m})\end{array}$ & $\begin{array}{l}\text { Maximum allowable variation for nominal } \\
\text { mass }\end{array}$ & $\begin{array}{l}\text { Section area (mm } \\
2\end{array}$ & Perimeter \\
\hline 6.3 & 0.245 & $\pm 7 \%$ & 31,2 & 19.8 \\
\hline 8.0 & 0.395 & $\pm 7 \%$ & 50,3 & 25.1 \\
\hline 10.0 & 0.617 & $\pm 6 \%$ & 78,5 & 31.4 \\
\hline 12.5 & 0.963 & $\pm 6 \%$ & 122,7 & 93.3 \\
\hline 16.0 & 1.578 & $\pm 5 \%$ & 201,1 & 50.3 \\
\hline 20.0 & 2.466 & $\pm 5 \%$ & 314,2 & 62.8 \\
\hline 22.0 & 2.984 & $\pm 4 \%$ & 380,1 & 69.1 \\
\hline 25.0 & 3.853 & $\pm 4 \%$ & 490,9 & 78.5 \\
\hline 32.0 & 6.313 & $\pm 4 \%$ & 804,2 & 100.5 \\
\hline 40.0 & 9.865 & $\pm 4 \%$ & 1256,6 & 125.7 \\
\hline
\end{tabular}

Source: Adapted from ABNT NBR 7480 (2007).

The structure was initially designed with $15 \times 50 \mathrm{~cm}$ pillars, $15 \times 40 \mathrm{~cm}$ beams and a $10 \mathrm{~cm}$ thick slab. Figure 2 shows the modeling performed at Revit 2020. 


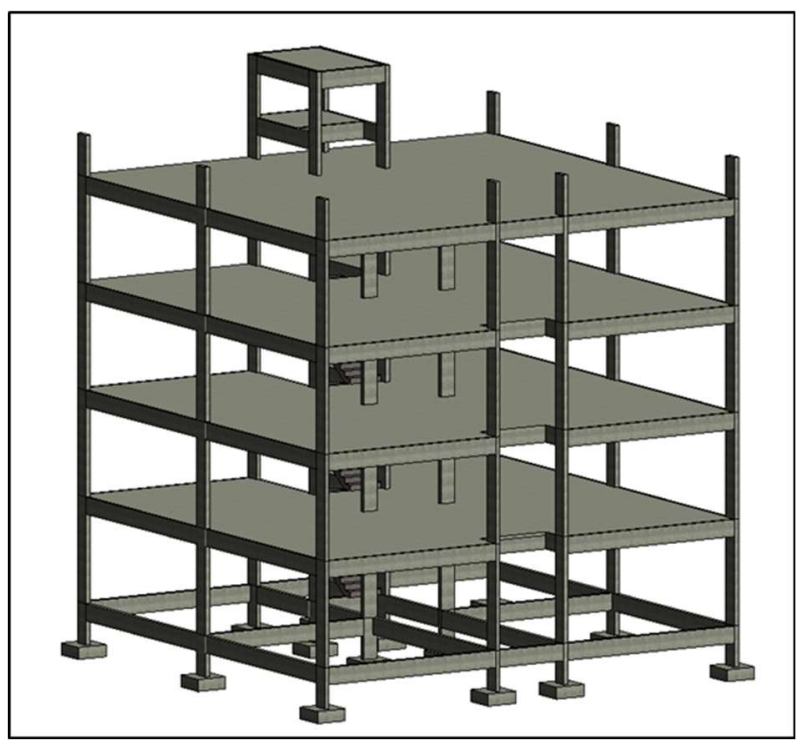

Figure 2: Modeling of the reinforced concrete structure held at revit 2020 (model I). Source: Revit (2020).

\section{Model II - Steel}

A36 steel was admitted for the metallic structure, its mechanical properties make it particularly suitable for structural applications, its low carbon content prevents the heat treatment from having much effect on this steel. According to ABNT NBR 8800 (2008), the value adopted for steel in the normal range of atmospheric temperatures, is $200 \mathrm{GPa}$ (gigapascal) for the modulus of elasticity (E); With 250 MPa yield strength $\left(f_{y}\right)$, and $400 \mathrm{MPa}$ yield strength $\left(f_{u}\right)$.

Figure 3 shows the initial modeling of the structure performed in Revit 2020 in a pre-dimensioning of the elements, for beams and columns, the W profile with dimensions of $10 \times 20 \mathrm{~cm}$ and reinforced concrete slab (same model used in method I) with thickness $10 \mathrm{~cm}$.

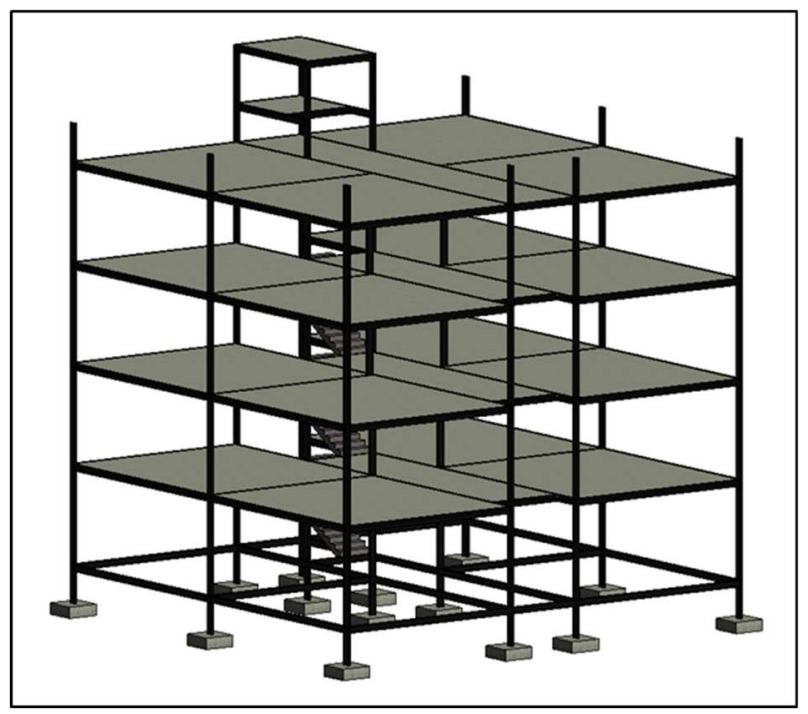

Figure 3: Modeling of the steel structure carried out in revit 2020 (model II). Source: Revit (2020).

\section{RESULTS AND DISCUSSION}

The calculations and adjustments of the structural elements were performed to meet the necessary requirements regulated in standards. With the Robot Structural Analysis program, it was possible to carry out analyzes of the displacements and efforts that requested the structure, corrections regarding the pre- 
dimensioning performed (Figures 2 and 3 ) and details of the reinforcement of the elements, thus guaranteeing structural safety and better use of the materials used. , avoiding an oversizing.

\section{Model I - Armed concrete}

For a reinforced concrete structure to be able to perform well, it must meet three main requirements, resistant capacity (rupture safety), in-service performance (controlled cracking) and durability (KIMURA, 2007). After modeling in Revit and dimensioning in Robot Structural Analysis, the structure was returned to Revit for details and quantitative extraction. For the model I in reinforced concrete, the beams had a variation in dimension, since what was established in the modeling did not meet the soliciting efforts to which the beam would be submitted. Therefore, respecting the minimum dimensions established by ABNT NBR 6118 (2014), the dimensions that were $15 \times 40 \mathrm{~cm}$ became $15 \times 55 \mathrm{~cm}$ so that they could reach the correct domain and the appropriate reinforcement and detailing rates (according to figure 4).

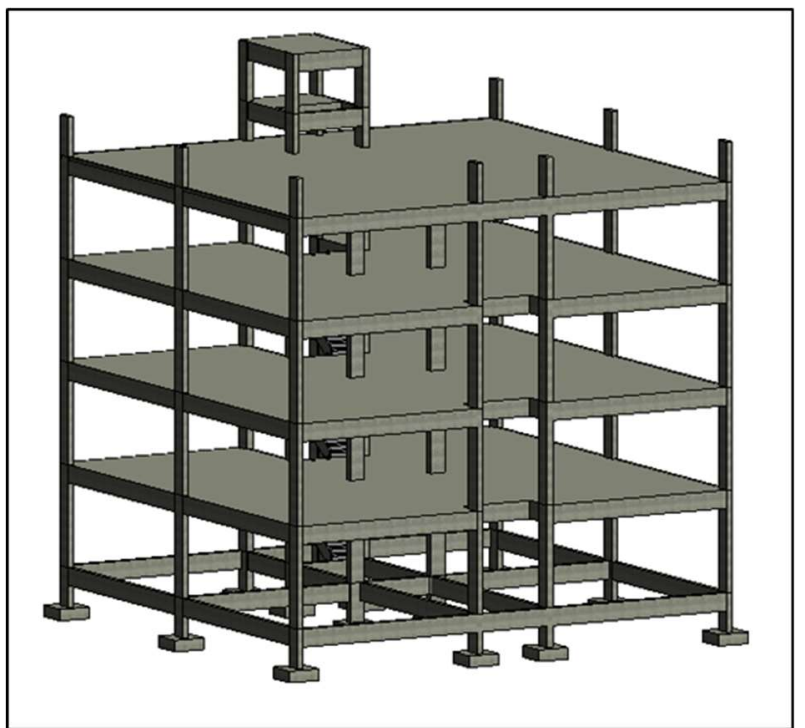

Figure 4: Sized armed concrete structure. Source: Revit (2020).

Figure 5 shows the beam with the reinforcement, it is observed that the diameter of the longitudinal bars was $20 \mathrm{~mm}$ and of the transversal bars $6.3 \mathrm{~mm}$.

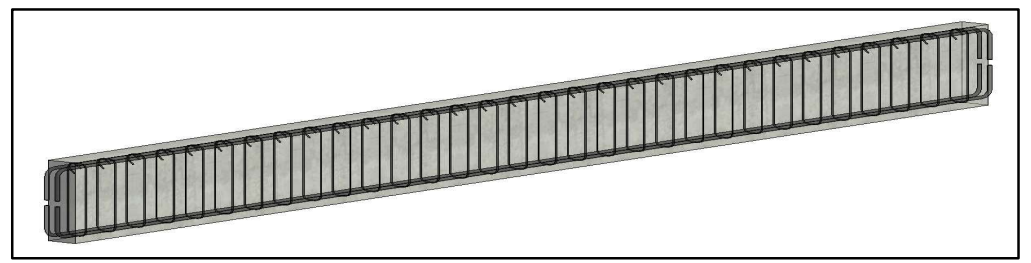

Figure 5: Beam detail. Source: Robot Structural Analysis (2020).

Briefly, for the beams, the longitudinal reinforcements admitted were bars with diameters of 8,16 and $20 \mathrm{~mm}$, while for transverse reinforcement bars with a diameter of $6.3 \mathrm{~mm}$. In order for the pillars to have acceptable levels of stability, they went from their initial dimension of $15 \times 50 \mathrm{~cm}$ to $20 \times 50 \mathrm{~cm}$. The position of the pillars in the structure can considerably affect the overall stiffness of the building, but since the purpose of the article is not this, the study of the best design was not taken into account. The column 
reinforcements that were subjected to composite flexion were obtained $12 \varphi 12.5 \mathrm{~mm}$ and some corner ones were admitted $8 \varphi 16 \mathrm{~mm}$, as shown in Figure 6 and table 4. Figures 7, 8 and 9 show graphs with the ratio of the volume of steel in $\mathrm{K}_{\mathrm{g}}$ and concrete per $\mathrm{m}^{3}$ in the structural elements.

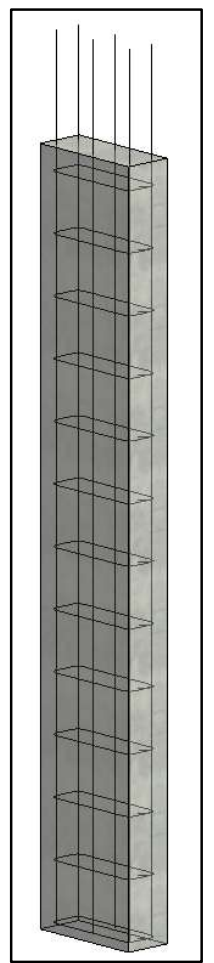

Figure 6: Detailing of pillars.

Quadro 4: Elementos estruturais.

\begin{tabular}{|c|c|c|c|c|}
\hline \multicolumn{5}{|l|}{ CONCRETE } \\
\hline Type $(\mathrm{cm})$ & Section $(\mathrm{cm})$ & Structural material & Concrete volume $\left(\mathrm{m}^{3}\right)$ & Amount \\
\hline Pillars & $20 \times 50$ & C30 & 22,60 & 12 \\
\hline Beams & $15 \times 55$ & C30 & 36,63 & 65 \\
\hline \multicolumn{2}{|l|}{ Total } & - & 59,23 & 77 \\
\hline \multicolumn{5}{|l|}{ STEEL BARS } \\
\hline Section (mm) & Structural material & Total Length (m) & Nominal mass $\left(\mathrm{k}_{\mathrm{g}} / \mathrm{m}\right)$ & Weight $\left(\mathrm{kg}_{\mathrm{g}}\right)$ \\
\hline $6,3 \mathrm{~mm}$ & CA50 & 5938,26 & 0,56 & 1458,87 \\
\hline $12,5 \mathrm{~mm}$ & CA50 & 856,62 & 0,963 & 824,93 \\
\hline $16 \mathrm{~mm}$ & CA50 & 1838,07 & 1,578 & 2900,47 \\
\hline \multicolumn{2}{|l|}{$20 \mathrm{~mm}$} & 1988,66 & 2,466 & 4904,04 \\
\hline \multicolumn{2}{|l|}{ Total } & 10621,61 & - & 10088,31 \\
\hline
\end{tabular}

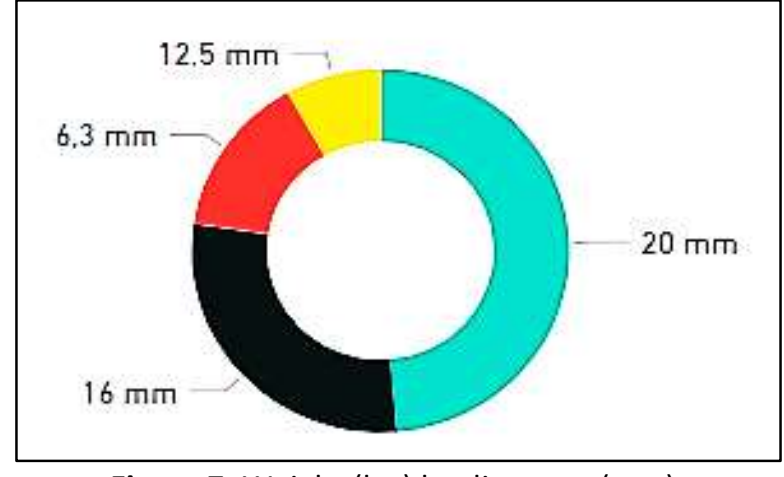

Figure 7: Weight $\left(\mathrm{kg}_{\mathrm{g}}\right)$ by diameter $(\mathrm{mm})$.

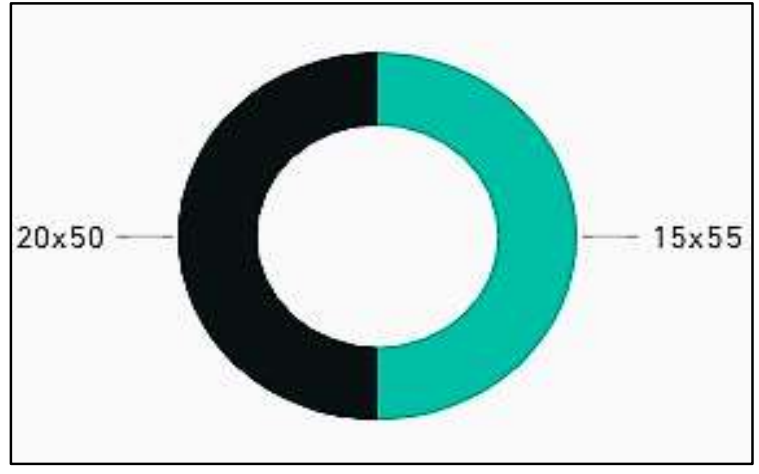

Figure 8: Weight $\left(\mathrm{k}_{\mathrm{g}}\right)$ by section. 


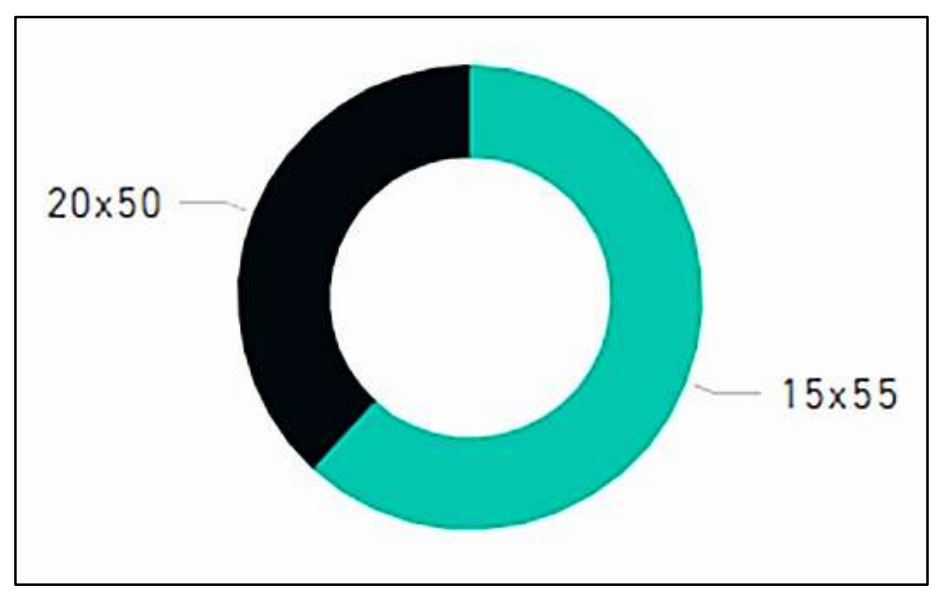

Figure 9: Concrete volume $\left(\mathrm{m}^{3}\right)$ by section.

\section{Model II - Steel}

According to ABNT NBR 8800 (2008), the safety of a metallic building is directly linked to the prevention of collapses, its good performance occurs avoiding the occurrence of displacements, vibrations and localized damage, which can be guaranteed from a correct structural design.

With the result of the design of the structural elements carried out by Robot Structural Analysis, it was found that the sections modeled in the Revit software with a $10 \times 20 \mathrm{~cm}$ W profile met the request of some beams, but for others a new design with a W profile was necessary. With dimensions of $14 \times 40.3 \mathrm{~cm}$ (the largest section being used for the beams). For the columns it was also necessary to have section profiles that were larger than those initially modeled, using a $15.2 \times 45 \mathrm{~cm}$ section $\mathrm{W}$ profile. The slabs remained 10 $\mathrm{cm}$ thick, as shown in figure 10 and table 5 .

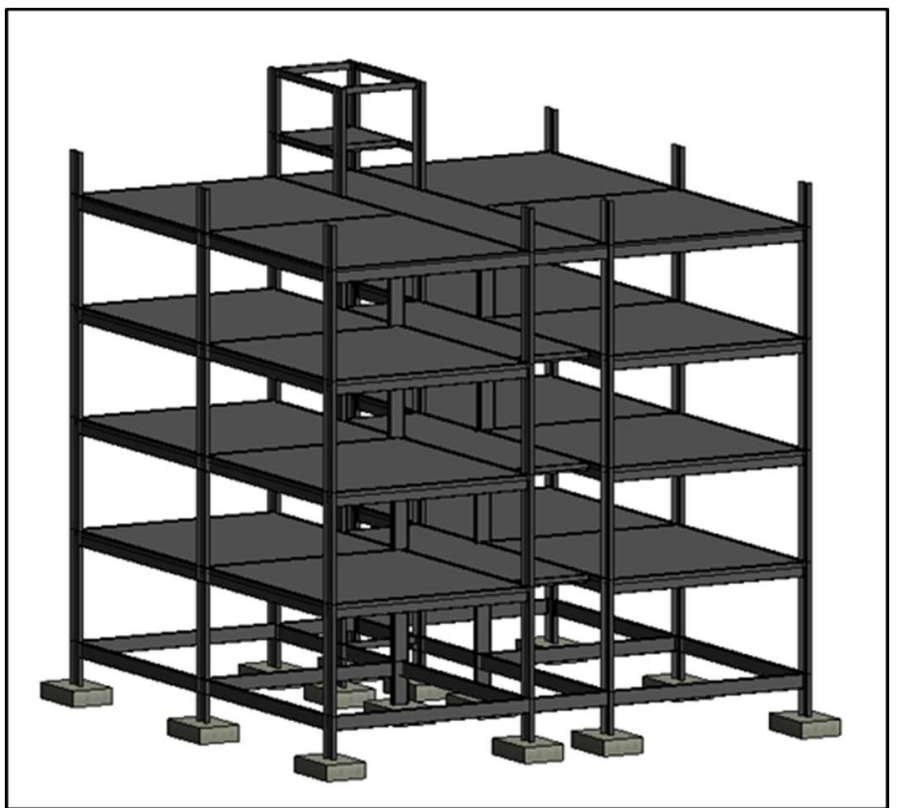

Figure 10: Dimensioned steel structure. Source: Revit (2020).

Table 5: Quantitative of pillars and beams.

\begin{tabular}{|c|c|c|c|c|c|}
\hline \multicolumn{6}{|c|}{ STRUCTURAL ELEMENTS } \\
\hline Type $(\mathrm{cm})$ & Section & $\begin{array}{l}\text { Structural } \\
\text { material }\end{array}$ & Steel volume $\left(\mathrm{m}^{3}\right)$ & Weight $\left(K_{g}\right)$ & Amount \\
\hline Pillars & W460X52 & ASTM A36 & 1,39 & 713,21 & 12 \\
\hline Beams & W200X15 & ASTM A36 & 0,08 & 21721,25 & 19 \\
\hline
\end{tabular}




\begin{tabular}{|l|l|l|l|l|l|}
\cline { 2 - 5 } Total & ASTM A36 & 2,67 & 10881,14 & 46 \\
\hline
\end{tabular}

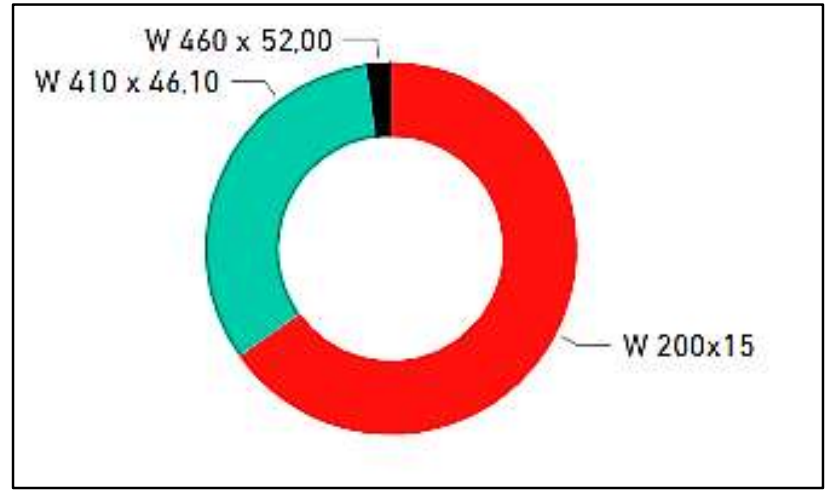

Figure 11: Weight $(\mathrm{kg})$ by section.

Figure 11 shows the graph that represents the volume of steel per section in $\mathrm{m}^{3}$. Figure 12 shows the profile model (W) used for the elements that make up the metallic structure, although the elements have sections with varying dimensions, they all follow the same profile.

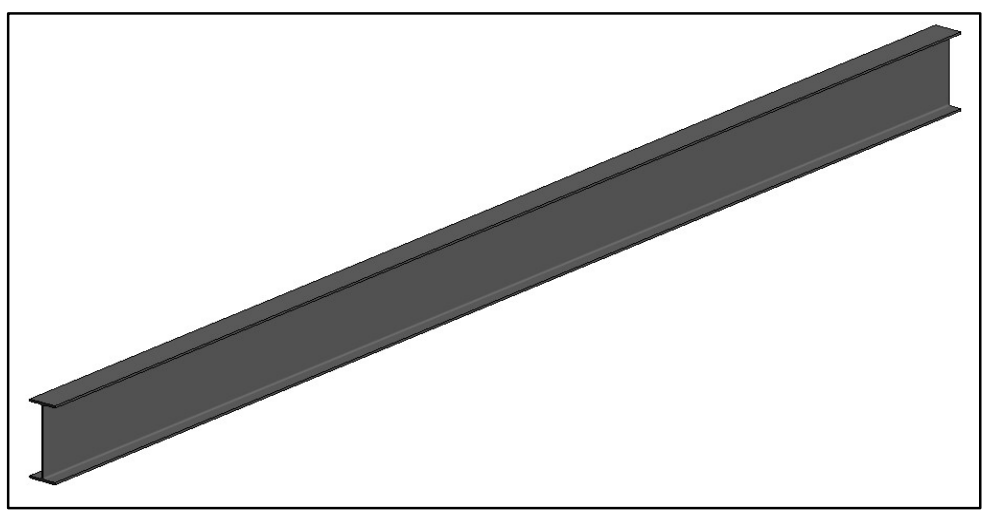

Figure 12: W profile. Source: Robot Structural Analysis (2020).

\section{Material Comparison}

Below are shown in table 6 , and in figures 13 and 14 the relationship and quantity of materials used in model I, in table 7 and figure 15, the relationship and quantity of materials used in model II. Thus, it is possible to make a brief comparison in relation to the quantity and cost of materials used in each structural model.

Table 6: Quantitative for structural elements (MODEL I).

\begin{tabular}{|c|c|c|c|c|c|c|c|c|}
\hline \multicolumn{9}{|c|}{ CONCRETE COST - MODEL I } \\
\hline Type (cm) & Section $(\mathrm{cm})$ & \multicolumn{2}{|c|}{$\begin{array}{l}\text { Structural material } \\
(\mathrm{MPa})\end{array}$} & \multicolumn{2}{|c|}{$\begin{array}{ll}\text { Concrete } & \text { volume } \\
\left(\mathrm{m}^{3}\right) & \end{array}$} & \multicolumn{2}{|l|}{ Cost $\left(\mathrm{R} \$ / \mathrm{m}^{3}\right)$} & $\begin{array}{l}\text { Total Costl } \\
\text { (R\$) }\end{array}$ \\
\hline Pillars & $20 \times 50$ & \multicolumn{2}{|l|}{$\mathrm{C} 30$} & \multicolumn{2}{|l|}{22,60} & \multicolumn{2}{|l|}{290} & 6554 \\
\hline Beams & $15 \times 55$ & \multicolumn{2}{|l|}{$\mathrm{C} 30$} & \multicolumn{2}{|l|}{36,63} & \multicolumn{2}{|l|}{290} & 10622,7 \\
\hline \multicolumn{2}{|l|}{ Total } & \multicolumn{2}{|l|}{-} & \multicolumn{2}{|l|}{59,23} & \multicolumn{2}{|l|}{-} & 17176,7 \\
\hline \multicolumn{9}{|c|}{ STEEL BAR COST - MODEL I } \\
\hline Section (mm) & $\begin{array}{l}\text { Structural } \\
\text { material }\end{array}$ & $\begin{array}{l}\text { Steel Volume } \\
\left(\mathrm{m}^{3}\right)\end{array}$ & \multicolumn{2}{|c|}{\begin{tabular}{|l|} 
Total Length \\
(m)
\end{tabular}} & $\begin{array}{l}\text { Nominal } \\
\text { mass }\left(k_{\mathrm{g}} / \mathrm{m}\right)\end{array}$ & Weight (kg) & $\begin{array}{ll}\text { Unit } & \text { Cost } \\
\left(\mathrm{R} \$ \mathrm{~K}_{\mathrm{g}}\right) & \\
\end{array}$ & $\begin{array}{l}\text { Total Cost } \\
\text { (R\$) }\end{array}$ \\
\hline $6,3 \mathrm{~mm}$ & CA50 & 0,19 & \multicolumn{2}{|c|}{5938,26} & 0,245 & 1454,87 & 4,8 & 6983,39 \\
\hline $12,5 \mathrm{~mm}$ & CA50 & 0,11 & \multicolumn{2}{|c|}{856,62} & 0,963 & 824,92 & 4,8 & 3959,64 \\
\hline $16 \mathrm{~mm}$ & CA50 & 0,37 & \multicolumn{2}{|c|}{1838,07} & 1,578 & 2900,47 & 4,8 & 13922,28 \\
\hline $20 \mathrm{~mm}$ & CA50 & 0,62 & \multicolumn{2}{|c|}{1988,66} & 2,466 & 4904,03 & 4,8 & 23539,37 \\
\hline \multicolumn{2}{|l|}{ Total } & & & & & & & 48404,68 \\
\hline
\end{tabular}




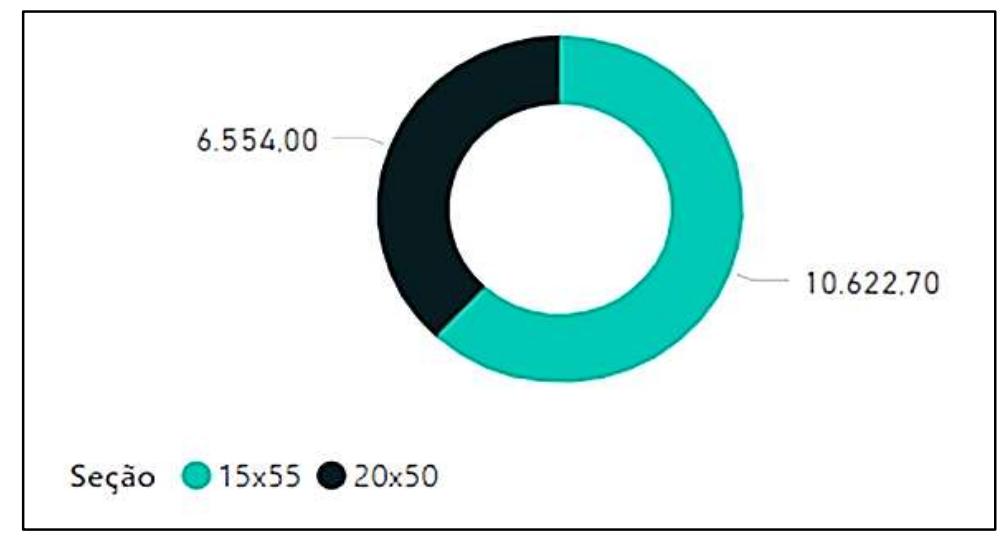

Figure 13: Concrete volume $\left(\mathrm{m}^{3}\right)$ by section and total cost ( $\$$ ).

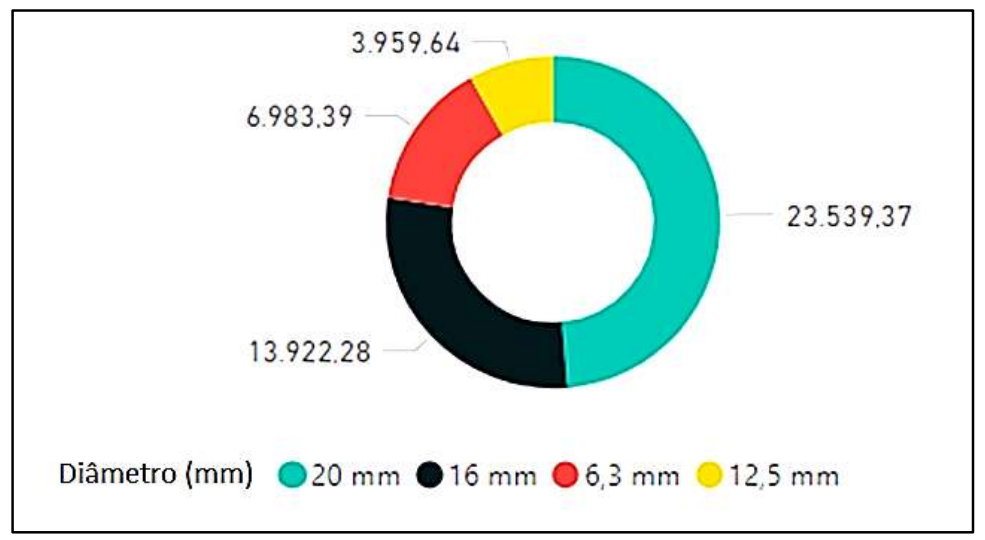

Figure 14: Weight $\left(\mathrm{k}_{\mathrm{g}}\right)$ by diameter $(\mathrm{mm})$ and total cost $(\mathrm{R} \$)$.

Table 7: Quantitative for structural elements (model II).

\begin{tabular}{|l|l|l|l|l|l|}
\hline METALLIC STRUCTURE COST - MODEL II & \multicolumn{5}{l|}{} \\
\hline \multirow{2}{*}{ Type $\mathbf{( c m )}$} & Section & $\begin{array}{l}\text { Structural } \\
\text { material }\end{array}$ & Weight (Kg) & Unit Cost (R\$/Kg) & Total Costl (R\$) \\
\hline Pillars & W460X52 & ASTM A36 & 713,21 & 6,11 & 4357,71 \\
\hline \multirow{2}{*}{$\begin{array}{l}\text { Beams } \\
\text { Total }\end{array}$} & W200X15 & ASTM A36 & 21721,25 & 6,11 & 132716,84 \\
\cline { 2 - 6 } & W410X46,10 & ASTM A36 & 10881,14 & 6,11 & 6643,77 \\
\hline
\end{tabular}

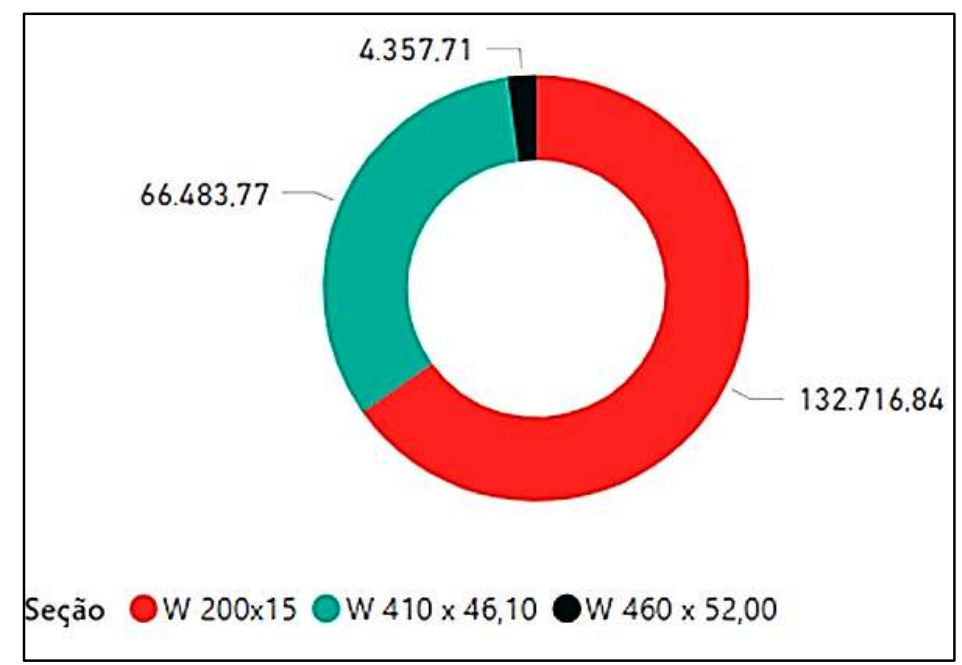

Figure 15: Weight $\left(\mathrm{k}_{\mathrm{g}}\right)$ by section and total cost $(\mathrm{R} \$)$.

The values used for the quantitative of the concrete C30 in $\mathrm{m}^{3}$ and of the Steels (CA50 and A36) in $\mathrm{k}$ $\mathrm{g}$, were based for the region where the hypothetical building is located. From the results regarding the costs and the amount of materials used for the structural models, it can be seen that the conventional reinforced 
concrete structure presented a much lower final cost compared to the metallic structure.

Since for the present study only the necessary quantity of each material and cost was analyzed, it is known that for a complete analysis as to the cost benefit between the construction methods, other factors must be taken into account, such as expenses with the foundation, labor, accessibility of materials to the construction site, among others.

\section{Global Stability}

Structures having high height are more likely to suffer due to instability caused by actions gravitational and lateral actions, so that the wind calculation on the structure becomes very important to assess the overall stability of an element or set of structural elements is a indispensable factor for structural design. Horizontal and vertical loads cause horizontal displacement to the structure's nodes, these nodes are separated as fixed and mobile (CARVALHO, 2013; ALVES et al., 2016).

The verification of $\gamma_{z}$, according to item 15.5.3 of NBR 6118: 2014, is valid for reticulated structures of at least four floors, thus, the verification of global stability by the parameter of z-range is shown in Figure 13. In order to assimilate the effects of the material on the behavior of the overall stability of the structure, it was noted that for the reinforced concrete model, the z-gamma values were lower than the steel model. For this analysis the only parameter considered was whether the building would reach stability, a more indepth study was not carried out verifying the section variation.

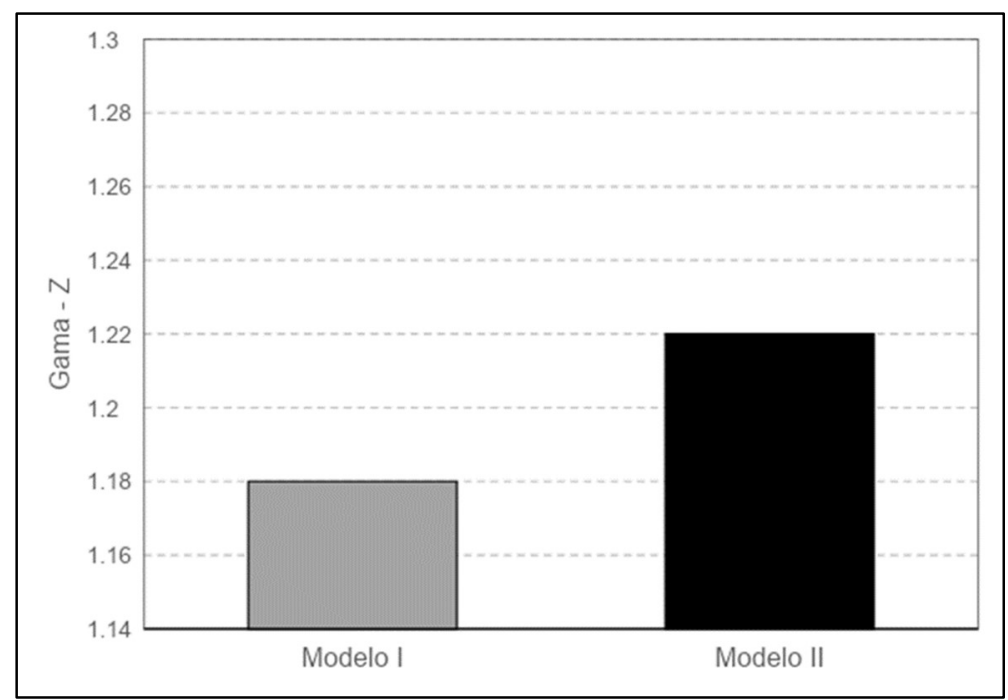

Figure 16: Variation of the z-range.

It is observed that in both cases the value was higher than the limit value for the structure to be classified as fixed nodes, which is 1.10 . Thus, the structures are considered to be mobile nodes, as indicated by NBR 6118 (ABNT, 2014). Classified as mobile nodes, the two structural systems have large displacements and therefore the second order effects must be considered. The program used calculates based on the $z-$ gamma value, when the z-gamma value is higher than the limit value of 1.30 the structure is considered unstable, in the cases analyzed, models I and II are considered stable, since their values were less than 1.30. 


\section{CONCLUSIONS}

The structural design and dimension consists of choosing a structural system that constitutes the resistant part of the building, seeking to meet the quality requirements established in the technical standards, regarding the resistant capacity, the performance in service, the durability of the structure and the prevention of collapses.

With buildings becoming more and more slender, looking for larger spans and structures with reduced section, it becomes important and advantageous to analyze the behavior of the structure, mainly with regard to its stability. In this way, structural modeling software becomes our allies, providing us with calculations closer to reality. In terms of costs in relation to the materials used, in a brief comparison between the structural systems, the reinforced concrete structure becomes more viable when compared to the metallic one, in terms of economy.

In view of the results obtained in the analysis carried out, it is concluded that both structural systems should be considered as mobile node structure, as they present large displacements and as model I obtained a lower z-gamma value than model II, it can be concluded that this is a more stable structure. This fact is quite common in reinforced concrete structures when compared to metallic structures, due to their own weight being greater than in metallic ones, consequently making the vertical forces larger and ultimately generating a smaller Z-range.

\section{REFERENCES}

ALVES, E. C.; PAIXÃO, J. F. M.. Analysis of global stability in tall buildings. Espírito Santo: Electronic Journal of Civil Engineering, 2016.

ABNT. Associação Brasileira de Normas Técnicas. NBR 7480: Steel intended for reinforcement for reinforced concrete structures: Specification. Rio de Janeiro: ABNT, 2007.

ABNT. Associação Brasileira de Normas Técnicas. NBR 6120: Loads for calculating structures and buildings. Rio de Janeiro: ABNT, 1980.

ABNT. Associação Brasileira de Normas Técnicas.NBR 6123: Forces due to wind in buildings. Rio de Janeiro: ABNT, 2013.

ABNT. Associação Brasileira de Normas Técnicas. NBR 8800: Design of steel structure and mixed steel and concrete structures of buildings. Rio de Janeiro: ABNT, 2008.
ABNT. Associação Brasileira de Normas Técnicas. NBR 6118: Design of Concrete Structure-Procedure. Rio de Janeiro: ABNT, 2014.

BOTELHO, M. H. C.; MARCHETTI, O.. Reinforced concrete I love you. 6 ed. São Paulo: Blucher, 2010.

CARVALHO, R. C.. Calculation and detailing of usual reinforced concrete structures: according to NBR 6118. 3 ed. São Paulo: EdUFSCar - Publisher at the Federal University of São Carlos, 2013.

CORTEZ, L. A. R.. Use of steel structures in Brazil. Monograph (Bachelor of Civil Engineering, Exact Sciences and Technology) - Federal University of Alagoas, Macéio, 2017.

KIMURA, A.. Informatics applied to reinforced concrete structures: building calculations using computer systems. São Paulo: PINI, 2007.

A CBPC - Companhia Brasileira de Produção Científica (CNPJ: 11.221.422/0001-03) detém os direitos materiais desta publicação. Os direitos referem-se à publicação do trabalho em qualquer parte do mundo, incluindo os direitos às renovações, expansões e disseminações da contribuição, bem como outros direitos subsidiários. Todos os trabalhos publicados eletronicamente poderão posteriormente ser publicados em coletâneas impressas sob coordenação da Sustenere Publishing, da Companhia Brasileira de Produção Científica e seus parceiros autorizados. Os (as) autores (as) preservam os direitos autorais, mas não têm permissão para a publicação da contribuição em outro meio, impresso ou digital, em português ou em tradução. 